\title{
Kegiatan Home Literacy Dalam Mengembangkan Kemampuan Awal Membaca Anak Usia Dini Di Masa Wfh
}

\author{
Erik $^{1}$, Badroeni $^{2}$, Nika Cahyati ${ }^{3}$ \\ PG PAUD STKIP Muhammadiyah Kuningan ${ }^{1,2,3}$. \\ erikwahyudin@upmk.ac.id ${ }^{1}$, badroeni@upmk.ac.id ${ }^{2}, \underline{\text { nika@upmk.ac.id }{ }^{3}}$
}

\begin{abstract}
Abstrak
Home Literacy adalah kegiatan belajar anak dalam pengembangan bahasa anak usia dini sebelum masuk lembaga PAUD yang membantu anak dalam kemampuan awal membaca anak, akan tetapi masih sedikit orang tua yang memahami akan pentingnya home literacy pada anak usia dini. Tujuan penelitian ini adalah untuk melihat pengaruh kegiatan home literacy terhadap kemampuan membaca awal anak. Penelitian menggunakan pendekatan kulitatif dengan pendekatan Fenomenalogi. Penelitian ini dengan membagi cluster orangtua dilihat dari tingkat pendidikan orangtua anak usia dini. Hasil dari penelitian ini orangtua yang memiliki tingkat pendidikan yang tinggi mempunyai kesadaran yang tinggi dalam melakukan home literacy kepada anak yang berdampak pada kemampuan anak dalam pengembangan bahasa yang lebih baik. Orangtua yang berlatar belakang pendidikan rendah, kurang kesadaran dalam melakukan home literacy dan tidak memahami dalam strategi pengajaran home literacy menjadikan anak tidak lebih baik dalam kemampuan membaca awal. Hal ini berdampak pada kesiapan anak sekolah pada jenjang pendidikan anak usia dini.
\end{abstract}

Kata Kunci: Home Literacy, Kemampuan membaca awal anak

\section{Abstract:}

Home Literacy is children's learning activities in early childhood language development before entering PAUD institutions that help children in early reading abilities of children, but only a few parents understand the importance of home literacy in early childhood. The purpose of this study was to see the effect of home literacy activities on children's early reading skills. The study uses a skinative approach with a phenomenological approach. This study by dividing the parent cluster seen from the level of education of parents of early childhood. The results of this study parents who have a high level of education have a high awareness in doing home literacy to children that have an impact on children's abilities in better language development. Parents with low education background, lack of awareness in doing home literacy and not understanding in home literacy teaching strategies make children not better in early reading skills. This has an

Kegiatan Home Literacy (Erik; Badrouni; Cahyati) 160 
Jurnal Golden Age, Universitas Hamzanwadi

Vol. 04 No. 1, Juni 2020, Hal. 160-166

E-ISSN : 2549-7367

impact on the readiness of school children at the level of early childhood education.

Keywords: Home Literacy, Early reading ability of children

\section{PENDAHULUAN}

Keadaan di luar prediksi berupa wabah penyakit covid-19 telah membawa perubahan yang mendesak pada berbagai sektor. Perkembangan virus dengan cepat menyebar luas di seluruh dunia. Setiap hari data di dunia mengabarkan bertambahnya cakupan dan dampak covid-19. Indonesia pun masuk dalam keadaan darurat nasional. Angka kematian akibat Corona terus meningkat sejak diumumkan pertama kali ada masyarakat yang positif terkena virus covid-19 pada awal Maret 2020. Hal tersebut mempengaruhi perubahan-perubahan dan pembaharuan kebijakan untuk diterapkan. Kebijakan baru juga terjadi pada dunia pendidikan merubah pembelajaran yang harus datang ke sekolah menjadi cukup di rumah saja. Sebanyak 13 negara termasuk Cina, Italia dan Jepang telah menutup sekolah-sekolah di seluruh negeri dalam upaya untuk menghentikan penyebaran virus mirip flu tersebut. Itu mempengaruhi hampir 290 juta siswa, kata UNESCO. Sebagian besar siswa berasal dari China, tempat wabah itu berasal. Di seluruh negeri, termasuk wilayah administrasi khusus Hong Kong dan Makau, lebih dari 233 juta siswa tidak sekolah karena virus. Itu diikuti oleh Jepang, yang memiliki hampir 16,5 juta siswa yang dipindahkan, menurut data UNESCO. Institute of Statistics. Sejumlah sekolah di Amerika Serikat telah membatalkan kelas akibat virus corona. Antaranya adalah Mariner High School dan Discovery Elementary School, yang terletak di negara bagian Washington, yang telah melihat peningkatan tajam dalam kasus yang dikonfirmasi. Negara bagian New York dan Kota New York juga telah menutup beberapa sekolah setelah pejabat kesehatan mengkonfirmasi setidaknya 22 kasus di seluruh negara bagian. Pejabat Los Angeles, ketika menyatakan keadaan darurat pada hari Rabu, mengatakan kepada orang tua bahwa penutupan sekolah adalah suatu kemungkinan dan harus disiapkan.

Pejabat kesehatan saat ini tidak merekomendasikan penutupan sekolah jika tidak ada kasus coronavirus lokal. Sebaliknya, mereka menekankan perilaku sehat seperti mencuci tangan dengan air sabun panas, tinggal di rumah saat sakit dan menutupi batuk. UNESCO akan mengadakan pertemuan darurat pada 10 Maret tentang penutupan sekolah terkait coronavirus. Badan tersebut mengatakan mendukung implementasi program dan platform pembelajaran jarak jauh skala besar untuk menjangkau siswa dari jarak jauh. Dampak pandemi corona kini mulai merambah dunia pendidikan, pemerintah pusat hingga daerah memberikan kebijakan untuk meliburkan seluruh lembaga pendidikan. Hal ini dilakukan sebagai upaya mencegah meluasnya penularan virus corona. Diharapkan dengan

Kegiatan Home Literacy (Erik; Badrouni; Cahyati) 161 
seluruh lembaga pendidikan tidak melaksanakan aktivitas seperti biasanya, hal ini dapat meminimalisir menyebarnya penyakit covid 19 ini. Hal serupa juga sudah dilakukan oleh berbagai negara yang terpapar penyakit covid 19 ini, kebijakan lockdown atau karantina dilakukan sebagai upaya mengurangi interaksi banyak orang yang dapat memberi akses pada penyebaran virus corona. Penelitian ini membahas mengenai home literacy yang dilakukan oleh orang tua saat kegiatan belajar dirumah.

Home literacy adalah kuantitas dan kualiats interaksi membaca bersama orang tua dan anak yang dilakuan sebelum anak memasuki lembaga pendidikan anak usia dini (Alhammadi, 2017). Home literasy dari sudut pandang teori perkembangan sosial konsturktivis dapat dilihat dari dua aspek yaitu sejauh mana interaksi orang tua dalam pengenalan huruf kepada anak dan orang tua sebagai model di mana banyak jenis peluang ketersedian buku cetak yang biasa dibaca orang tua yang memungkinkan anak ikut tertarik dalam membacanya (Bleses, Jensen, Højen, \& Dale, 2018). Home literacy merupakan bagian dari perkembangan bahasa, dimana kecerdasan bahasa harus diberikan melalui stimulus oleh orangtua atau guru(Pendidikan \& Indonesia, n.d.) Bahasa merupakan salah satu aspek perkembangan yang harus cara yang menyampaikan orang lain . keinginannya Seperti pada keterampilan lainnya, anak pun harus belajar untuk berbicara. Melalui berbicara anak dapat berkomunikasi.Dewasa ini kasus keterlambatan berbicara pada anak usia dini sering terdengar. Ayuandia, dkk (2017) dalam penelitiannya penyebab menyatakan kurang bahwa dengan lingkungan dikembangkan menstimulusnya, dengan stimulasi diberikan harus sesuai dengan tahapan perkembangan anak agar berkembang secara optimal. Selain itu, karena bahasa juga memiliki peranan yang sangat penting bagi anak dalam menjalani kehidupannya .

Pentingnya bahasa dalam optimalnya keterampilan berbicara anak karena kosakata yang dimiliki anak belum sesuai dengan usianya, juga masih ditemukan anak yang struktur kehidupan karena bahasa merupakan alat komunikasi yang digunakan ketika manusia berkomunikasi satu sama lain dalam kehidupan seharihari. Hurlock menjelaskan bahwa kalimatnya belum mencapai standar sesuai tahap perkembangan berkomunikasi dapat dilakukan dengan setiap bentuk bahasa, seperti isyarat, emosional, atau keterampilan berbicaranya, selain itu kurangnya kosakata yang dimiliki oleh anak dapat menyebabkan anak belum bisa berkomunikasi dengan baik dalam menyampaikan keinginannya. Salah satu kegiatan yang dapat dilakukan dalam mengembangkan bahasa tulisan, tetapi komunikasi yang paling dan paling dilakukan dengan cara berbicara. Keterampilan berbahasa meliputi keterampilan menyimak, keterampilan membaca, keterampilan berbicara, dan keterampilan menulis. Seseorang yang 
memiliki keterampilan berbicara dapat keterampilan berbicara anak adalah dengan menerapkan metode bercerita pada anak. Metode bercerita merupakan salah satu metode pembelajaran yang digunakan di dalam pendidikan anak.

Pengenalan membaca awal anak penting dilakukan sejak anak masih berada di lingkungan rumah dan belum memasuki lembaga pendidikan anak usia dini (PAUD) dengan mendesain lingkungan rumah seperti di kamar anak dengan tersedia APE yang menstimulus mengenalkan keaksaran anak serta dibantu dengan keterlibatan orangtua dalam mengenalkan keaksaraan melalaui kegiatan bermain di dalam rumah.Tujuan penelitian ini adalah untuk mengetahui epektivitas dari belajar mengenal keaksaraan di rumah dalam mengembangkan kemampuan membaca awal anak usia dini serta menambah wawasan nuansa ke ilmuan literasy earliychildhood.

\section{METODE PENELITIAN}

Jenis penelitian ini adalah kualitatif dengan pendekatan study kasus. Hal ini melihat situasi kondisi di mana didasarkan pada situasi kondisi yang terjadi di Indonesia di mana aktifitas anak tidak bisa belajar di ruang kelas sekolah,dan dilakukan di rumah masing-masing di mana keterlibatan orangtua sangat berperan aktif sejalan dengan aktifitas orangtua yang harus bekerja di rumah yang disebabkan oleh fandemi Covid 19. Jenis penelitiannya mengarah pada kajian fenomenologis yang memiliki perhatian khusus terhadap fenomena yang diteliti, fokus terhadap kegiatan subjek penelitian, mengugkapkan permasalahan, memaparkan data, menganalisis data, serta mendapat data dengan cara observasi langsung. Subjek penelitian adalah anak-anak usia dini dengan mengamati beberapa anak beserta orangtua mereka di wilayah Kabupaten Kuningan Jawabarat.

\section{HASIL PENELITIAN DAN PEMBAHASAN}

Kemampuan berbahasa sebaiknya diawali dari rumah, karena orang tua adalah madrasah pertama bagi anak, semakin sering orang tua mengajak anak berkomunikasi, maka kemampuan anak dalam berbahasa akan semakin baik, semakin sering anak dilibatkan dalam aktivitas orang tua, maka rasa ingin tahu anak akan semakin tinggi. Hal ini menunjukan bahwa pentingnya peran orang tua dalam perkembangan bahasa anak. Home Literacy yang dilakukan oleh anak dengan pendampingan orangtua di masa Covid 19 memberikan dampak yang signifikan terhadap kemampuan awal membaca anak. Hal ini sejalan dengan penelitian sebelumnya yang dilakukan oleh(Roberts, Jergens, \& Burchinal, 2005) bahwa kegiatan home literacy menjadi faktor yang kuat di dalam pengembangan kemampuan membaca awal anak. Selama WFH, anak akan semakin dekat dengan orang tuanya, orang tua pun semakin aktif dan mencari berbagi ide demi 
keterlaksanaanya pembelajaran dirumah yang efektif dan menyenangkan, berdasarkan hasil pengamatan bahwa orang tua berusaha mencari ide agar anak mau belajar di rumah, berbagai cara dilakukan, salah satu upaya mereka adalah selalu mendampingi anak dalam melakukan kegiatan pembelajaran yang diberikan guru untuk anak, waktu pelaksanaan pembelajaran juga tidak menentu, karena mengkuti kemauan anak, agar proses belajar dapat terlaksana dengan menyenagkan dan menghasilkan pembelajaran yang efektif.

Melihat dari beberapa aspek yang dilakukan di rumah (Frekuensi membaca buku orangtua, strategi membaca ibu, kesenangan atau antusisas anak belajar membaca, dan sensitivitas ibu) anak lebih cepat dalam kemampuan awal mebaca.Keterbaruan dalam penelitian ini bahwa pemanfaatan WFH di rumah bisa dimanfaatkan dengan kegiatan home literacy yang melibatkan antara orangtua dan anak-anak usia dini dengan aktifitas bermain di sekitar rumah dengan mendesain lingkungan rumah kepada hal yang menstimulus anak dalam pengenalan huruf dan kosa kata (Dethorne, 2015). Beberapa penelitian juga menunjukan bahwa home literacy meningkatkan kemampuan berbahasa anak, kemampuan anak dalam membaca, serta kemampuan anak dalam berkomunikasi, hal ini disebabkan adanya attachment atau kelekatan antara orang tua dan anak, sehingga pembelajaran dengan mudah menyerap pada anak. Tidak sedikit juga orang tua yang mengeluhkan pembelajaran di rumah, karena mereka sering kali kesulitan dalam menerapkan pembelajaran, aktivitas anak di luar rumah atau bermain dengan teman-temannya dirasa menjadi kendala, namun hal ini justru memicu untuk orang tua agar memanfaatkan hal ini. Orang tua memanfaatkan kegiatan bermain anak untuk meningkatkan kemampuan berbahsa anak, kemudian orang tua memanfaatkan moment WFH untuk mendesign lingkungan rumah dalam meningkatkan kosakata anak. Orang tua selama WFH dapat lebih focus pada anak, sehingga dapat melihat sejauh mana kemampuan perkembangan bahsa anak. Dengan mendesign kegiatan bermain anak, maka anak akan mampu meningkatkan kosatakatanya tanpa adanya stimulus khusus, karena orang tua akan lebih focus dan dapat meningkatkan attachment untuk anak.

Home literacy dalam penelitian Michele Hood dengan penelitian longitudinal selama 3 tahun (Hood, Conlon, \& Andrews, 2008) Preschool Home Literacy Practices and Children 's Literacy Development : A Longitudinal Analy hasil penelitian tersebut bahwa praktik keaksaraan di rumah prasekolah dan keaksaraan anak dan perkembangan bahasa ada korelasi positif dalam kemampuan membaca awal anak dengan sampele 143 anak di negara Australia. Goodman\&Goodman,1976 penelitian ini mendokumentasikan bahwa konstruksi pengetahuan keaksaraan berlangsung baik di rumah maupun di sekolah,dalam bingkai ini, mereka belajar dari buku cetak menandakan bahasa dan tentang 
sifat,karekteristik, dan bentuk bahasa dari bahasa tulis yang mereka alami(Purcellgates, 1996). Berdasarkan hasil pengataman juga menunjukan bahwa orang tua jadi lebih focus dalam pengasuhan anak, sehingga meningkatkan kemampuan literacy anak.

Berdasarkan pengamatan pada orang tua yang memiliki tingkat pendidikan yang rendah menujukan bahwa kurang kesadaran dalam melakukan home literacy dan tidak memahami dalam strategi pengajaran home literacy menjadikan anak tidak lebih baik dalam kemampuan membaca awal. Hal ini berdampak pada kesiapan anak sekolah pada jenjang pendidikan anak usia dini yang tidak lebih baik daripada anak-anak yang berada pada lingkungan sosial yang mendukung dalam pendidikan. Mereka menganggap bahwa kemampuan anak dalam membaca maupun menulis itu sepenuhnya tanggung jawab sekolah, dan tanggung jawab guru, sehingga kurangnya kemampuan anak dalam berbahasa, orang tua menganggap bahwa anak tidak perlu diajarkan membaca karena anak akan bisa sendiri, sehingga beberapa orang tua membiarkan anaknya bermain begitu saja tanpa ada tujuan khusus untuk meningkatkan kemampuan bahsa anak. Sehingga perlu penanaman kembali kepada orang tua yang menganggap bahwa home liretacy tidak penting diterapkan pada anak.Manfaat dari penelitian ini menambah khazanah ke ilmuan earlychildhood dan menambah wawasan bagi orangtua dan masyarakat pada umumnya akan pentingnya kegiatan home literacy.

\section{KESIMPULAN}

Kegiatan Home literacy bermanfaat bagi anak di dalam pengembangan kemampuan membaca dan pengembangan bahasa pada umumnya. Orangtua harus mempunyai kesadaran akan pentingnya home literacy dan memahami startegi kegiatan home literacy yang efektif, seperti orang tua melibatkan anak dalam aktifitas membaca keseharian, bagaimana startegi ibu dalam membaca (membaca dengan suara nyaring) menumbuhkan antusias anak dalam membaca,dan membangun sensitivitas ibu dalam pendampingan/keterlibtan keseharian di rumah. Manfaat dari penelitian ini menambah khazanah ke ilmuan earlychildhood dan menambah wawasan bagi orangtua dan masyarakat pada umumnya akan pentingnya kegiatan home literacy.

\section{DAFTAR PUSTAKA}

Aswasulasikin, A., Ibrahim, D. S. M., \& Hadi, Y. A. (2020). Penciptaan Lingkungan Ramah Literasi Melalui Partisipasi Masyarakat. Jurnal Dimaswadi, 1(1), 1-7.

Alhammadi, F. S. (2017). ScienceDirect Prediction of child language development: A review of literature in early childhood communication disorders. Lingua. https://doi.org/10.1016/j.lingua.2017.07.007 
Bleses, D., Jensen, P., Højen, A., \& Dale, P. S. (2018). Infant Behavior and Development An educator-administered measure of language development in. Infant Behavior and Development, 52(June), 104-113. https://doi.org/10.1016/j.infbeh.2018.06.002

Dethorne, L. S. (2015). Rethinking environmental influences on child language development. Journal of Communication Disorders, 57, 1-2. https://doi.org/10.1016/j.jcomdis.2015.09.002

Handoko, H., \& Novitasari, K. (2019). Model Multisensori Berbasis Teknologi Multimedia untuk Pembelajaran Literasi Anak Usia Dini. Jurnal Golden Age, 3(02), 64-72.

Hood, M., Conlon, E., \& Andrews, G. (2008). sisPreschool Home Literacy Practices and Children's Literacy Development: A Longitudinal Analy. 100(2), 252-271. https://doi.org/10.1037/0022-0663.100.2.252

Khotijah, I. (2018). Peningkatan kemandirian anak melalui pembelajaran practical life. Jurnal Golden Age, 2(02), 127-140.

Nahdi, K., \& Yunitasari, D. (2019). Literasi Berbahasa Indonesia Usia Prasekolah Ancangan Metode Dia Tampan dalam Membaca Permulaan. Jumal Obsesi: Jumal Pendidikan Anak Usia Dini, 4(1), 446-453

Nahdi, K., Ramdhani, S., Yuliatin, R. R., \& Hadi, Y. A. (2020). Implementasi Pembelajaran pada Masa Lockdown bagi Lembaga PAUD di Kabupaten Lombok Timur. Jurnal Obsesi: Jurnal Pendidikan Anak Usia Dini,5(1), 177-186..

Nahdi, K., \& Yunitasari, D. (2019). Inside-outside circle: An early childhood language and literacy development method. International Journal of Innovation, Creativity and Change, 5(6), 325-335.

Novitasari, K. (2019). Penggunaan Teknologi Multimedia Pada Pembelajaran Literasi Anak Usia Dini. Jurnal Golden Age, 3(01), 50-56.

Pendidikan, F. I., \& Indonesia, U. P. (n.d.). STUDI KASUS PERKEMBANGAN KETERAMPILAN BERBICARA ANAK USIA DINI MELALUI PENERAPAN METODE BERCERITA PENDAHULUAN 29-37.

Purcell-gates, V. (1996). Stories, coupons, and the TV Guide: Relationships between home literacy experiences and emergent literacy knowledge. 31(4), 406-428.

Roberts, J., Jergens, J., \& Burchinal, M. (2005). The role of home literacy practices in preschool children's language and emergent literacy skills. Journal of Speech, Language, and Hearing Research.

Safira, A. R. (2018). Intervensi Keluarga Melek Huruf: Solusi Yang Layak Untuk Meningkatkan Kebiasaan Membaca Keluarga Sosioekonomi Rendah Di Indonesia. Jurnal Golden Age, 2(02), 113-126. 